An official publication of the International Society for Energy, Environment and Sustainability (ISEES)
Journal of Energy and
Journal homepage : www.jees.in

\title{
Distribution of BTEX in Soils of an Urban Area: Kanpur Region, India
}

\author{
Avinash Gupta, Aditya Kumar Jha, Amit Kumar Singh, Prashant Rajput and Tarun Gupta* \\ Department of Civil Engineering and APTL at Center for \\ Environmental Science and Engineering (CESE), IIT Kanpur, Kanpur- 208016
}

\section{A R T I C L E I N F O}

Received : 20 June 2019

Revised : 28 August 2019

Accepted : 04 October 2019

Keywords:

BTEX; Soil.

\begin{abstract}
A B S T R A C T
Benzene, Toluene, Ethylbenzene and Xylenes (BTEX) are among the most harmful volatile organic compounds (VOCs) present in our ambient environment in all the three media namely, air, water and soil. They are included in the priority list by USEPA (the United States Environmental Protection Agency) as most hazardous substances. These are harmful to humans; benzene is a well-known carcinogenic compound. Present study was conducted to evaluate BTEX concentration in the soil samples collected from Kanpur region inside the IIT Kanpur campus as well outside the campus these sites are residential, commercial, rural, industrial and highway locations. Gas Chromatography-Flame Ionization Detector (GC-FID) was used to determine the concentration of BTEX in this study. A total of 140 samples were collected and analyzed to determine the concentration of BTEX in soil samples. Five specific sites were chosen for the samples collection: 28 samples have been collected from each area viz. IITK campus, Shivli, Bithoor, Panki and Jajmau. The maximum BTEX concentration in soil samples observed was $87.4 \mathrm{mg} / \mathrm{kg}$ at Jajmau site. Toluene concentration was higher than other compounds at all the sites. The VOCs concentration levels at other sites were in the order of Jajmau $>$ Panki>Bithoor $>$ Shivli $>$ IIT campus. The average concentration of total BTEX varied e.g. at IIT campus $(33.5 \pm 16.5 \mathrm{mg} / \mathrm{kg})$, at Shivli $(36.6 \pm 13.2 \mathrm{mg} / \mathrm{kg})$, at Bithoor $(52.3 \pm 4.9 \mathrm{mg} / \mathrm{kg})$, at Panki $(60.2 \pm 11.3$ $\mathrm{mg} / \mathrm{kg})$ and at Jajmau $(69.9 \pm 8.7 \mathrm{mg} / \mathrm{kg})$. Our study documents the baseline information of BTEX concentrations in the soil samples in Kanpur.
\end{abstract}

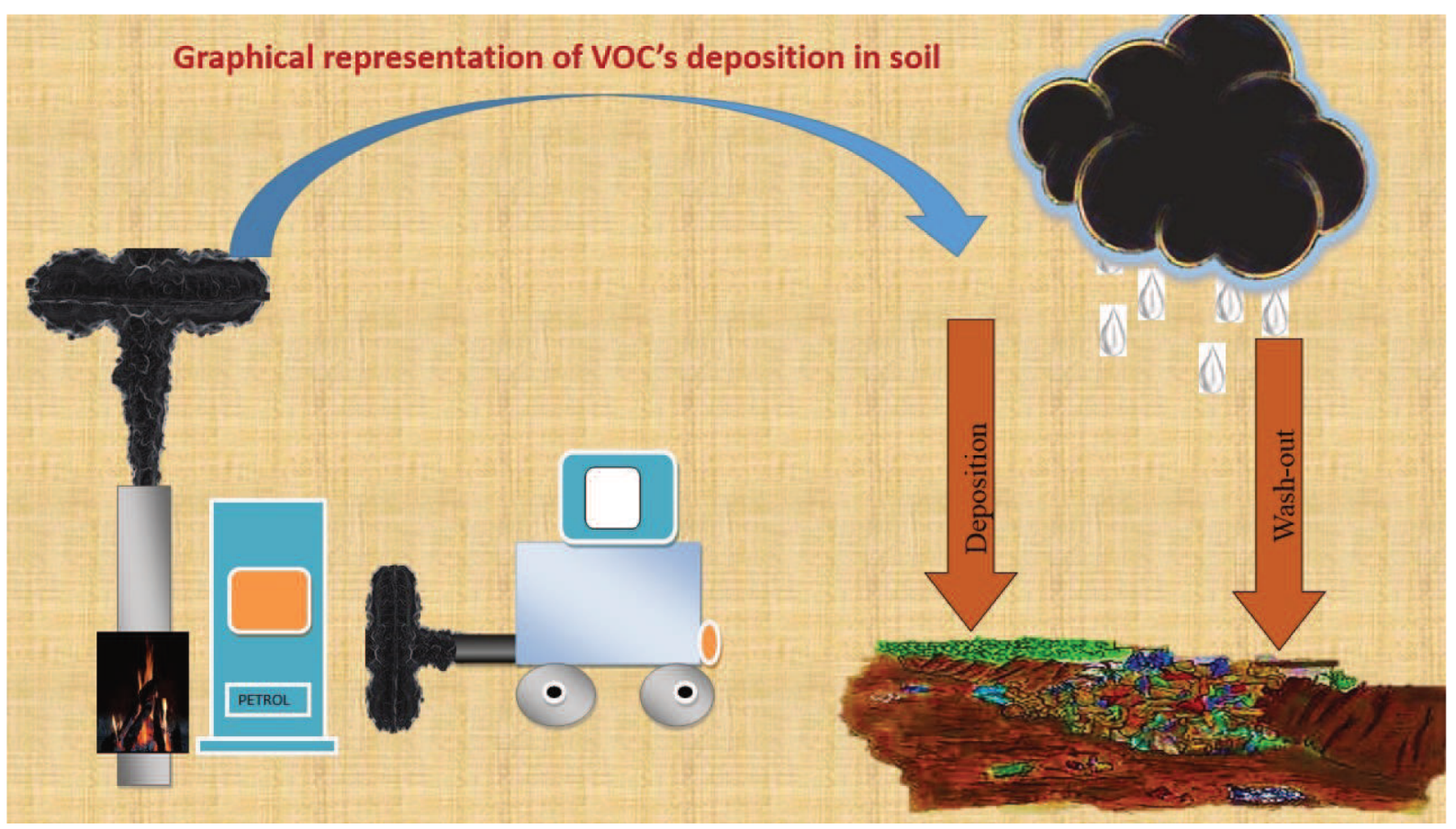

\footnotetext{
*Corresponding Author: : tarun@iitk.ac.in
} 


\section{Introduction}

Poor air quality is toxic for living beings as well our ecosystem, due to the noxious air 1,10,000 children died in India in 2016 (WHO 2011). Introduction of VOC's (volatile organic compounds) in the environment affects human health and atmospheric composition and chemistry. VOCs are emitted from biogenic (72\%) and anthropogenic source $(28 \%)$ (USEPA 2017). The primary anthropogenic sources of VOCs include their emission from diesel engines, combustion of gasoline, cigarette smoke, biomass burning etc. (Faraji et al. 2017). Researchers pay great attention on VOCs (ubiquitous in the environment) due to their potential role in secondary organic aerosols (SOA) formation and carcinogenic potential of some of them (Pratt et al. 2013). Benzene, toluene, ethylbenzene and xylenes, collectively known as BTEX are a group of VOCs having a significant impact on indoor and outdoor air quality. They represent an immense threat to humans due to their toxicity (Miller et al. 2011). Groundwater and soils are getting contaminated by BTEX. Accidental oil spills, transportation, vehicular emissions, leaching from landfill sites are sources of BTEX (Mitra et al. 2011) Ambient scavenging and diffusion are the most common pathways for these air pollutants to contaminate the soil (Agarwal et al. 2009). BTEX collectively can comprise about $60 \%$ of total non-methane VOCs production in an urban area (Hoque et al. 2008). BTEX have been recognized as toxic, carcinogenic and mutagenic in an urban environment (Bono et al. 2003). BTEX can enter the human body quickly through inhalation and can cause acute health risk even upon exposure at low concentrations affecting different target organs e.g. central nervous system, respiratory system, liver, kidney, reproductive system etc. (Buczynska et al. 2009). The study of BTEX in environmental samples (for example, soil samples in this study) is utmost important because of their toxic nature. Air quality standard concentrations of benzene showed in Table 1.

Table 1: Air quality standards for benzene in different countries

\begin{tabular}{l|l|l}
\hline S. No. & Country & Standard concentrations \\
\hline 1. & UK & $16 \mu \mathrm{g} / \mathrm{m}^{3}$ \\
2. & European commission & $5 \mu \mathrm{g} / \mathrm{m}^{3}$ \\
3. & Japan & $3 \mu \mathrm{g} / \mathrm{m}^{3}$ \\
4. & WHO guidelines & $5-20 \mu \mathrm{g} / \mathrm{m}^{3}$ \\
\hline
\end{tabular}

http://www.cpcbenvis.nic.in/newsletter/benzenefeb2002/feb2002.htm

The adverse effects of BTEX on human health are of great concern (Zhang et al. 2012). More than 99\% exposure to benzene occurs via inhalation WHO Air quality guidelines for Europe, 2000, 50\% of BTEX, inhaled by humans get absorbed in the human body. European legislation has set a permissible limit of $5 \mu \mathrm{g} / \mathrm{m}^{3}$ for benzene in urban ambient air (Marc et al. 2015). Outdoor activity is responsible for indoor air quality has been studied widely. For example, a study reported indoor air levels of BTEX in Gorakhpur experiencing influence from different outdoor environments viz. agriculture $\left(54.3 \mu \mathrm{g} / \mathrm{m}^{3}\right)$, industrial $\left(18.2 \mu \mathrm{g} / \mathrm{m}^{3}\right)$, roadside $\left(12.3 \mu \mathrm{g} / \mathrm{m}^{3}\right)$, and residential $\left(6.1 \mu \mathrm{g} / \mathrm{m}^{3}\right)$ (Masih et al. 2017). Toluene was always found more than benzene except in rural locality in their study, BTEX compounds eventually tranform into toluene while getting decomposed in natural environment (Dhada et al. 2014). They also reported seasonal variation in BTEX concentration: winter (32.5 $\left.\mu \mathrm{g} / \mathrm{m}^{3}\right)$, monsoon $\left(19.9 \mu \mathrm{g} / \mathrm{m}^{3}\right)$ and summer $\left(14.4 \mu \mathrm{g} / \mathrm{m}^{3}\right)$. The study done in Tehran by (Miri et al. 2016) reported outdoor annual average BTEX concentration of $\left(40.5 \mu \mathrm{g} / \mathrm{m}^{3}\right)$. They reported a strong correlation between different compounds, signifying origin from the same source. Cooking fuels on combustion emit various toxic compounds such as $\mathrm{CO}$, NOx, Benzene, PAHs etc. Air fresheners, insect repellents, perfumes and deodorants are also sources of BTEX. Burning of scented candles and incense are also the sources of BTEX (Masih et al. 2017). (Nespeca et al. 2019) and (Ahmad et al. 2019) determined BTEX in soil using Ultra-fast gas chromatographic with flame ionization detector (UFGC-FID), andsulfur-oxidizing bacterial (SOB) bioassay respectively. The major outdoor source of BTEX is vehicular exhaust emissions and biomass burning (Miri 2016; Chenye et al. 2019).

Some studies have been previously carried out in Indian cities like Delhi and Mumbai (Srivastava et al. 2006) over a period from 2001 to 2002. They have reported total BTEX concentration of $395 \mu \mathrm{g} / \mathrm{m}^{3}$ and $654 \mu \mathrm{g} / \mathrm{m}^{3}$ at those places, respectively. The benzene concentration constituted more than $70 \%$ and $50 \%$ of the total BTEX concentration in Delhi and Mumbai, respectively. The study by Hoque et al. (2008) observed that BTEX concentration at the roadside near AIIMS (All India Institutes of Medical Sciences) in Delhi was $456 \pm 224 \mu \mathrm{g} / \mathrm{m}^{3}$. Major constituents of the total BTEX concentration were toluene $(42-50 \%)$ and benzene (26-30\%). Many previous studies have also focused assessing BTEX near to the petrol pump station to infer about health effects of concerned workers (Singh et al. 2013).

The indoor sources of BTEX include combustion processes like cooking, heating and burning. These organic pollutants contaminate soil and groundwater once they enter in these environmental bodies (Buddhadasa et al. 2002). USEPA (United States Environmental Protection Agency) has recommended and categorized these compounds in the list of hazardous air pollutants (HAPs) (Kumar et al. 2017). There are several studies (Buddhadasa et al. 2002) carried out elsewhere focusing on assessment of BTEX in soil samples. This study focuses to assess the concentration of BTEX in soil samples (Fig. 1) inside the institutional campus of Indian Institute of Technology Kanpur (IIT Kanpur) and outside the campus in Kanpur region.

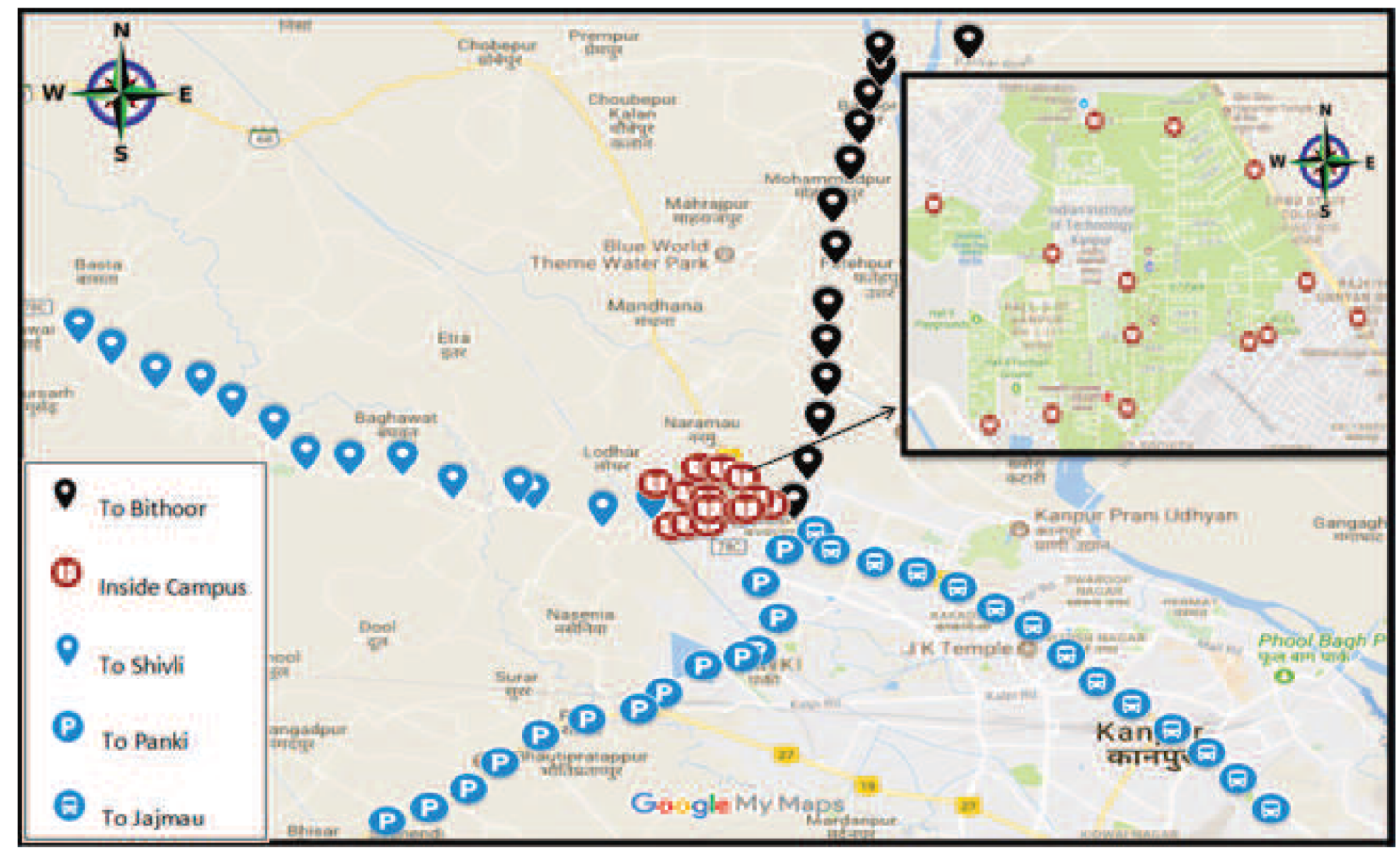

Fig.1. Map showing the soil sampling locations in Kanpur region 
Several studies have reported BTEX in air and soil, however still there is a scarcity of information regarding the distribution of BTEX in soil, sampling and analysis of different soil samples would provide more information on environmental trends in the soil environment. To the best of our knowledge study on the distribution of BTEX and risk assessment in soils remains limited. We aimed to cover different sites ie; agricultural, residential, academic and industrial site the results of this study could provide a baseline dataset (in soil) of the occurrence and outcomes of BTEX contamination.

\section{Materials and methods:}

\subsection{Sampling site description}

The Kanpur metropolitan area is located in the state of Uttar Pradesh. The city experiences high pollution episodes in the world as per the WHO Ambient Air pollution city database, 2011(WHO 2011). The region experiences massive emissions of organic compounds and inorganic species due to various anthropogenic emission sources (Zytner et al. 1994). Previous studies have assessed inhalation impact of atmospheric particulate matter from this location. The sampling locations are shown in Fig. 1. Incampus (IIT Kanpur) and out-campus (Bithoor, Jajmau, Panki and Shivli or Sheoli) soil sampling has been carried out in this study. In out-campus sampling, the soil samples were collected along the roadside at every kilometer distance.

i. IIT Kanpur: This $\left(26.3^{\circ} \mathrm{N}, 80.1^{\circ} \mathrm{E}\right)$ is one of the leading academic institutes in India with a residential facility for students, faculty and staff (nearly 10,000 people residing on campus). One of the best campus in this region.

ii. Bithoor Area: This is a small town area $\left(26.6^{\circ} \mathrm{N}, 80.2^{\circ} \mathrm{E}\right)$ situated on the bank of the holy Ganga river. Most of the area included residential pockets and some part is agricultural land. Biomass burning and vehicular emissions appears visually major sources of VOC's pollution in this site

iii. Jajmau area: This site $\left(26.4^{\circ} \mathrm{N}, 80.4^{\circ} \mathrm{E}\right)$ is a significant industrial suburb in Kanpur. Site has a number of leather tanneries. This site is recognized as leather hub of state of Uttar Pradesh, Vehicular emission and industrial emission appears major source of VOCs in this area. Public transport has a heavy flow in this area.

iv. Panki area: This area $\left(26.4^{\circ} \mathrm{N}, 80.2^{\circ} \mathrm{E}\right)$ is another noteworthy suburb in Kanpur region. Site has the combination of commercial, residential, industrial and a thermal power plant. Vehicular emissions and emission from the thermal power plants appears the major source of BTEX in this site.

v. Shivli area: Shivli or Sheoli is a locality in village area of Kanpur. It is located at $26.3^{\circ} \mathrm{N} 80.3^{\circ} \mathrm{E}$. Since the area has village set up, it is representative of a rural site. In this area biomass burning, wood burning and vehicular emissions could be the sources of BTEX pollution. Vehicular traffic is minimum in this area as compared to above sampling stations.

\subsection{Soil sample collection}

Soil samples inside the institute campus (IIT Kanpur) and other four locations ranges from silty sand and clayey soils (Jishnu et al. 2013). Top $2 \mathrm{~cm}$ of the soil layer was discarded to remove the interfacing layer and then approximately $50 \mathrm{~g}$ of soil was taken in a pre-cleaned jar (Buddhadasa et al. 2002). Samples were taken about $1 \mathrm{~m}$ away from the roadside at every $1 \mathrm{~km}$ distance. Samples were also collected on the other side of the road. The samples were analyzed within 2 weeks' time from collection as suggested by a previous study (Trapido et al. 1999).

\subsection{Experimental}

Soil samples were homogenized in a container and left for air drying to remove moisture. The samples were then sieved through $2 \mathrm{~mm}$ sieve. 5 $\mathrm{g}$ of the sieved sample was taken into a pre-cleaned glass vial for solvent extraction. Subsequently, a $250 \mu \mathrm{L}$ of toluene-d8 from $1000 \mathrm{ppm}$ stock solution was added as a surrogate standard and the lid was closed using Teflon cap to minimize the losses of volatile compounds and left for $1 \mathrm{~h}$. Then $20 \mu \mathrm{L}$ of $\mathrm{n}$-hexane was used for soaking the doped soil sample for $\sim 12 \mathrm{~h}$. The sample was sonicated for $1 \mathrm{~h}$, extract was transferred into another vial and the same process was repeated with further $20 \mu \mathrm{L}$ and 10 $\mu \mathrm{L}$ of $\mathrm{n}$-hexane for $1 \mathrm{~h}$ and 30 minutes, respectively. All the extracts of a sample were pooled and filtered through a $0.22 \mu \mathrm{m}$ Millipore filter using a glass syringe. A $1 \mu \mathrm{L}$ of this filtered extract was transferred in a GC-vial and $25 \mu \mathrm{L}$ of fluorobenzene from $200 \mathrm{ppm}$ stock solution was added as an internal standard. A $2 \mu \mathrm{L}$ solution was injected into GC-FID. Retention

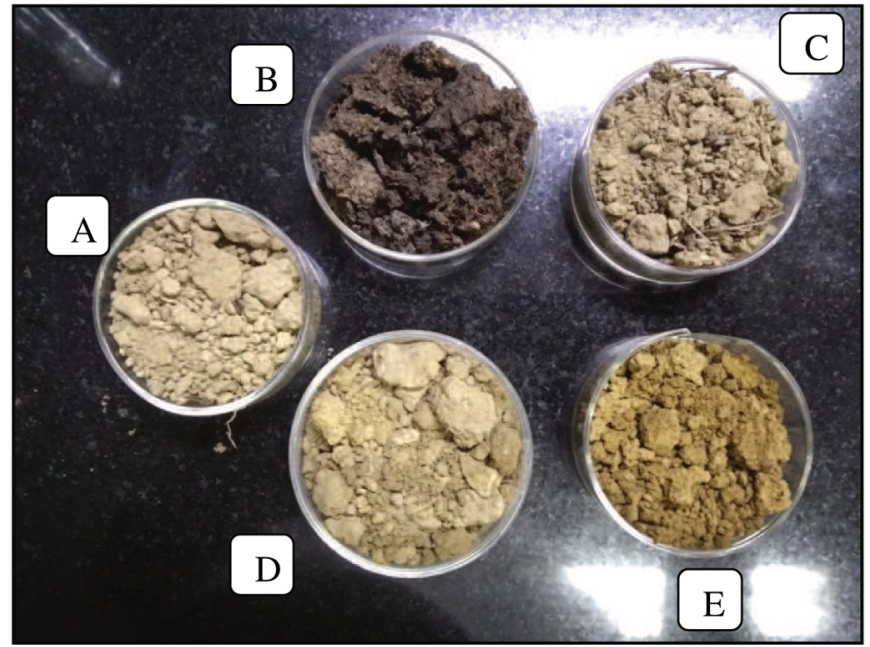

Fig.2. Soil images of the samples collected from different sites (A) IIT campus (B) Shivli (C) Bithoor (D) Panki (E) Jajmau

time and identification of each analyte was monitored by running individual standard. A 5 point calibration was achieved routinely with freshly prepared mix standards of BTEX $(\mathrm{R} 2>0.99)$ and the quantification of these compounds in a batch of samples was obtained against the calibration plot

\section{Results and discussion}

\subsection{Concentration of the pollutants at the sampling locations:}

The average levels of BTEX inside the campus and outside the campus are given in Table 2. BTEX concentration is much higher outside the campus as compared to in-campus values. That may be due to the heavy traffic congestion, industrial emissions and biomass burning.

Table2. BTEX concentrations measuredat different sites in Kanpur inthis study

\begin{tabular}{l|l|l}
\hline S. No. & Location & Concentration $(\mathrm{mg} / \mathrm{kg})$ \\
\hline 1. & IIT campus & $33.5 \pm 16.5$ \\
2. & Shivli & $36.6 \pm 13.2$ \\
3. & Bithoor & $52.3 \pm 4.9$ \\
4. & Panki & $60.2 \pm 11.3$ \\
5. & Jajmau & $69.6 \pm 8.7$ \\
\hline
\end{tabular}

The average concentration of BTEX in IIT Kanpur campus was (33.5 $\pm 16.5) \mathrm{mg} / \mathrm{kg}$ (Fig. 3). The concentration in right $(62.1 \mathrm{mg} / \mathrm{kg})$ and left $(53.7 \mathrm{mg} / \mathrm{kg})$ direction $(\sim 500 \mathrm{~m})$ away from the IIT gate are higher due to huge vehicular emissions on the National Highway. Burning of waste and biomass were also found during sampling in these locations. The concentration at IIT gate $(58.6 \mathrm{mg} / \mathrm{kg})$ was observed to be maximum at the periphery of the campus. It is more than the concentration in the left direction. The major reason is the proximity to the railway crossing which witnesses frequent vehicle stoppage. Here, pollutants are expected to accumulate from vehicles exhaust due to more waiting time of vehicles (engine idling) until the crossing is unoccupied. The concentration at motor transport area (MT) crossing $(44.4 \mathrm{mg} / \mathrm{kg}$ ) was also quite high due to the traffic load at this crossing. Concentration in front of KendriyaVidyalaya (KV) School was $34.3 \mathrm{mg} / \mathrm{kg}$. Major sources could be higher frequency of school vans stoppage and commuters. However, BTEX concentration is less than those observed at the above mentioned sites plausibly due to less inflow and outflow of vehicles at this site as compared to other sites. 
BTEX Concentration at IITK

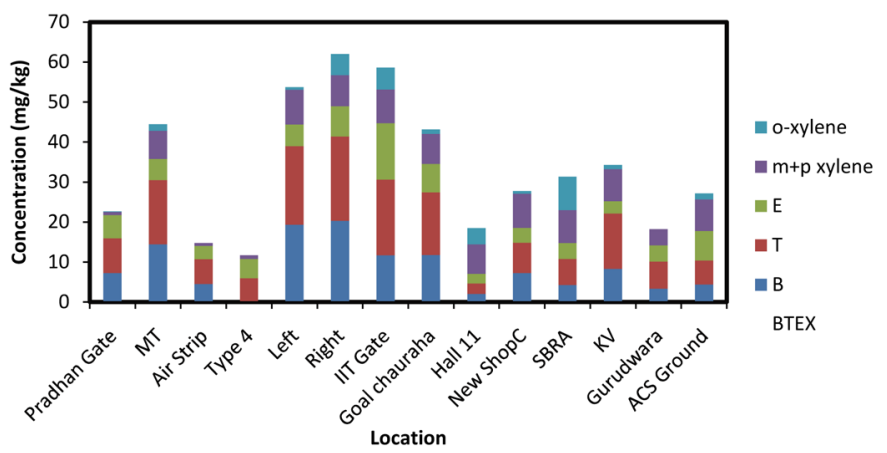

Fig.3. Concentrationof BTEX insoil samplescollectedwithin thephysicalboundary of our institutional campus (IIT Kanpur)

In Shivli sampling region (Fig. 4) the average BTEX concentration near the road was $36.6 \pm 13.1 \mathrm{mg} / \mathrm{kg}$. The sampling and analysis at Shivli roadside were done in winter. The BTEX concentrations measured at several sites in the Shivli were lower than those situated in-campus (IITK campus). The roadsides have small point sources of BTEX at this site such as small dhabas using coal and wood. Also the residents in the area use wood as kitchen fuel. However, the major source of BTEX at this site appears as vehicular exhaust.

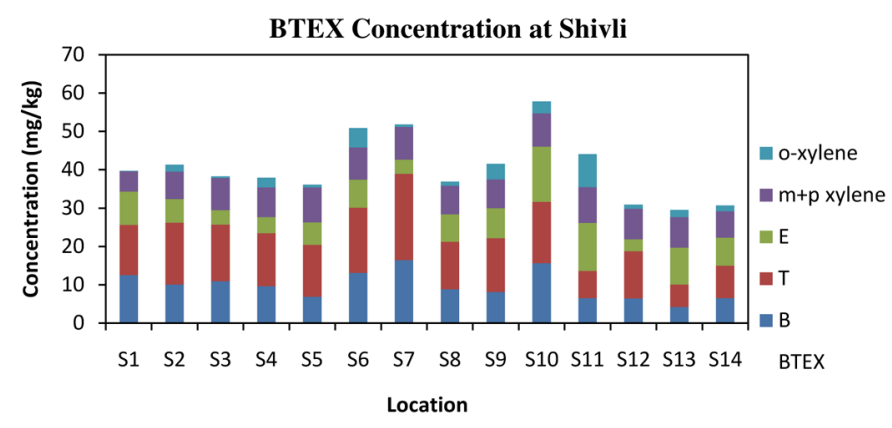

Fig.4 Concentration of BTEX insoil samplescollected from Shivli

Bithoor that is known as a tourist place situated on bank of the River Ganga. The concentration of BTEX (Fig. 5) on this place was $52.3 \pm 4.9$ $\mathrm{mg} / \mathrm{kg}$. The major source of BTEX in this area appears to be two-wheeler motor vehicles. The concentration of BTEX in soil on the roadside of Bithoor area is slightly higher than Shivli road plausibly due to more vehicular traffic.

\section{BTEX Concentration at Bithoor}

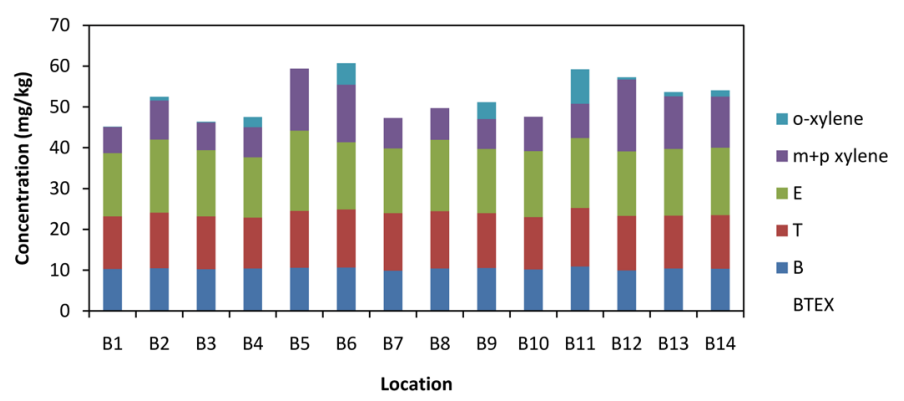

Fig.5. Concentrationof BTEX insoil samplescollected from Bithoor

Panki sampling station is a pilgrimage and industrial area. The BTEX concentration in Panki (Fig. 6) was $60.2 \pm 11.3 \mathrm{mg} / \mathrm{kg}$. Two wheelers, four wheelers and heavy loaded commercial vehicles are the main source of pollutants in this area. BTEX concentration at power plant site (P5) was found very high i.e. $79.7 \mathrm{mg} / \mathrm{kg}$. This can be due to the deposition of pollutants emitted from coal burning in Panki thermal power plant. At junction nearby SAIL (P7), the concentration was highest, that is, 81.6 $\mathrm{mg} / \mathrm{kg}$. BTEX concentrations at nearby stations were also high due to proximity of road traffic signal and zone of railway crossing. There are some commercial vehicle repairing shops located on this highway which might be acting as point sources of pollutants due to leakage of engine oil during servicing of vehicles and causing contamination of soil.

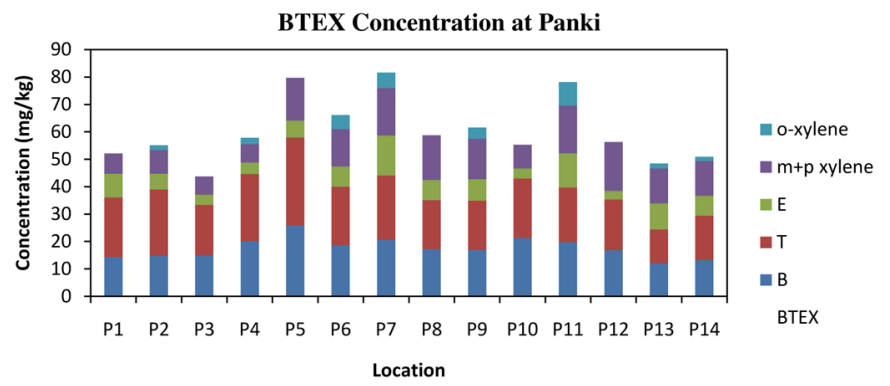

Fig.6. Concentrationof BTEX insoil samples collected from Panki

The BTEX concentration at the Jajmau site (Fig. 7) was $69.9 \pm 8.7$ $\mathrm{mg} / \mathrm{kg}$. This is likely due to heavy duty vehicles like buses, truck, two and four-wheelers running on this road. Passenger three wheelers auto rickshaw motors are also responsible for the contamination of air and soil because of the emissions from inefficient and old engine combustion. They stay in idle condition for most of the times at traffic signals while keeping the engine "ON" and thus cause huge pollution. These are the major source of emission at Imperial heights site (J1: $82.1 \mathrm{mg} / \mathrm{kg})$. Another site with elevated BTEX concentration was found at Bagiya railway crossing. Intersections such as 9 Number crossing (J5: $73.7 \mathrm{mg} / \mathrm{kg}$ ) and Gurudev, have high BTEX concentration. BTEX concentration at Golchauraha (J7) is high $(87.4 \mathrm{mg} / \mathrm{kg}$ ) plausibly due to a high frequency of vehicles. These findings demonstrate the transport and migration of BTEX in the soil samples.

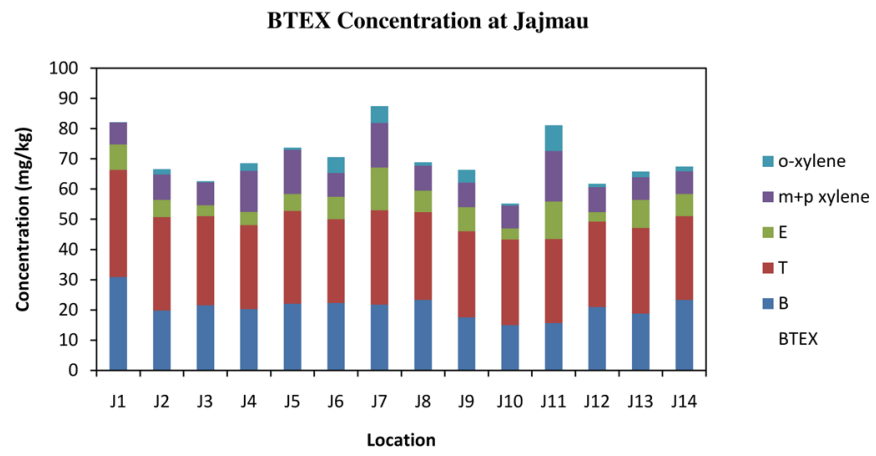

Fig.7. Concentrationof BTEX insoil samplescollected from Jajmau

\subsection{Comparison among different sites:}

The comparison of BTEX abundance at all sampling stations is described below. The traffic load in the road to Jajmau is highest among all the sites. Since four major cities are connected by Jajmau road, there is usually a heavy traffic congestion on this road which includes various types of commercial and private vehicles. It has road connectivity with public places like Kalyanpur, Rawatpur railway stations, Gurudev railway crossing and other important intersections due to which it is the most crowded roadway site among the investigated sites.

Panki has a less traffic as compared to the Jajmau site. When we proceed to SAIL junction, wherein road traffic increases, the traffic on this road is mixed i.e. largely private vehicles, heavy-duty vehicles, and four wheelers, but the concentration is a bit less than Jajmau.

On the road to Bithoor and Shivli road, the traffic was low. This is also reflected in BTEX concentrations in these areas in soil samples. Furthermore, the soil on Shivli road was less contaminated with BTEX. The concentration varied much in a distance of $1 \mathrm{~km}$, this signifies the main reason of pollutant is located nearby the sampling site and deposition occurs in the soil. 


\subsection{Remediation Technologies:}

This section provides future scope of this work. In view of their ubiquitous presence in our environment and negative effects on human health, numerous remediation methods have been suggested previously for the removal of VOCs from contaminated water, air and soil media (Peng 2003; Chan et al., 2012, Justicia-Leon et al., 2014, Li et al., 2012, Randazzo et al., 2011, Rodríguez et al., 2005, Tsai et al., 2010, Wei and Seo, 2010, Yokosuka et al., 2009).

Severaltechnologies, shown in Fig. 8. including electrolysis, aerobic degradation, condensation, adsorption, thermal combustion, catalytic oxidation, photocatalytic oxidation, phytoremediation have been proposed for the VOCs removal. Adsorption is the process in which VOCs are physically removed and it's a highly effective process (Srivastava et al. 2018).

In electrolysis method an alternating current is allowed to flow through an aqueous solution at both high and low voltages. The entire process of electrolysis is carried out in an electrolytic cell. In this cell, the ions migrate towards/away from the anode or cathode. It takes a lot of energy to separate the water into hydrogen and oxygen. This process is rarely used but convenient and also efficient way for the remediation of VOC's.

Aerobic degradation is the breakdown of organic contaminants with the aid of microorganisms in presence of molecular oxygen. Many organic contaminants are rapidly degraded under aerobic conditions by the aerobic bacteria. Aerobic degradation typically occurs more rapidly than anaerobic degradation. On the contrary, anaerobic degradation process reduces the volume and mass of waste materials and produces natural gas. Anaerobic digestion technology is widely used for the waste management system and as a source for production of renewable energy.

Phytoremediation is a cost-effective approach wherein plants are utilized for environmental remediation of soils, sludges, sediments, surface water and groundwater. However, phytoremediation has some demerits, such as detoxification process is very slow, it takes long time in month to years as the plants grows then it works for process (Aken 2008).

VOCs are thermally degraded at higher temperatures ranging above $900{ }^{\circ} \mathrm{C}$. Organic contaminants in air can be utilized as a fuel and its combustion can be allowed to occur in an internal combustion engine. The incineration can achieve effective destruction of VOC's within a short time leading to low processing cost. However, this process also has several disadvantages such as low efficiency and high energy consumption.

Zerovalent iron (ZVI) is most commonly used for environmental remediation. ZVI is typically applied as a reductant in the treatment of organic and inorganic contaminants found in various environmental media including groundwater and soil. Iron serves as the electron donor to reductively de-chlorinate VOCs to their non-chlorinated products and chlorine ions. ZVI has been shown previously to treat effectively various contaminants like chlorinated solvents, metals, aromatic compounds, nitrate and certain dyes. ZVI can be applied in both ex situ and in situ remediation.

Oxidation is a process that utilizes ultraviolet light (UV) and chemical

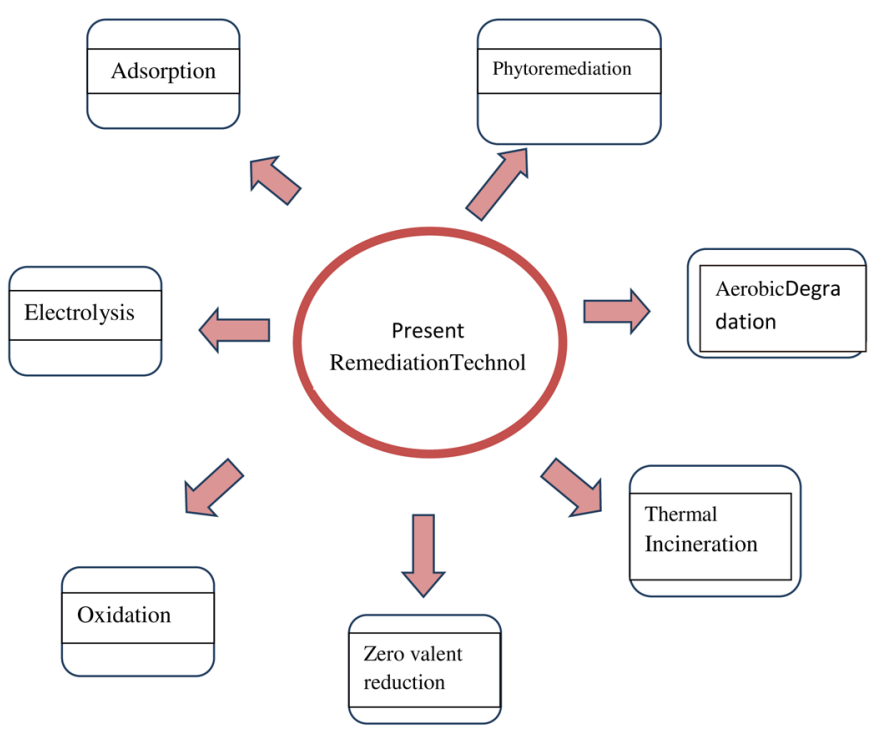

Fig 8: Showing important technologies for VOC's remediation oxidants such as ozone $\left(\mathrm{O}_{3}\right)$ and hydrogen peroxide $\left(\mathrm{H}_{2} \mathrm{O}_{2}\right)$ to destroy organic contaminants in groundwater. In this processes, the organic contaminants are transformed into carbon dioxide and water. This is a fast remediation process due to participation of ozone. Its demerits are high cost and induced ozone toxicity contaminants due to BITEX.

\section{Conclusions:}

We undertook soil campaign in Kanpur, India. Analyzed BTEX in soil samples using GC-FID. A total of 140 samples were collected in January 2018, Jajmau and panki were hotspots of BTEX pollution. Toluene concentration was higher as compare to other compounds. During this study it was found that total BTEX concentration was highest at Jajmau site and it was higher by a factor of 2 or more as compared that at other sites. Vehicular emissions, coal/wood combustion and thermal power plant are the major factors responsible for the variability of BTEX concentration at the sites. All these pollutant species are produced mainly from manmade activities. It has been observed that the most polluted site is Jajmau $>$ Panki>Bithoor $>$ Shivli $>$ inside the institute campus. Interestingly, there was a noticeably large variability in the concentration of BTEX within $15 \mathrm{~km}$ radius of IITK campus. Biomass burning and vehicular emission should be minimized to prevent these toxic pollution.

\section{Acknowledgments:}

This work has been carried out utilizing internal funds received from civil engineering department of Indian Institute of Technology Kanpur.

\section{References:}

1. WHO, 2011.World Health Organization. An overview of the evidence on environmental and occupational determinants of cancer. International Conference on Environmental and Occupational Determinants of Cancer, Interventions for Primary Prevention.Austuria, Spain.

2. Badjagbo, K., Loranger, S., Moore, S., Tardif, R., Sauve, S., 2010. BTEX Exposures among Automobile Mechanics and Painters and their associated health risks. Hum. Ecol. Risk Assess. 16, 301-316.

3. U.S.EPA (2017) Volatile Organic Compounds Emissions. EPA's Rep Environ 1990:

4. Faraji A, Nabibidhendi G, Pardakhti A (2017) Risk assessment of exposure to releasedBTEX in district 12 of Tehran municipality for employees or shopkeepers and gas station customers. Pollution 3:363-375. https://jpoll.ut.ac.ir/ article_61806.html.

5. Pratt, G. C., Palmer, K., Wu, C. Y., et al. (2000). An assessment of air toxics in Minnesota. Environmental Health Perspective, 108, 815-825. https:// www.ncbi.nlm.nih.gov/pubmed/11017885.

6. Miller L, Xu X, Wheeler A, Atari O D, Grgicak- Mannion, Luginaah I (2011) Spatial variability and application of ratios between BTEX in two Canadian Cities Scientific World Journal 11:2536-2549. https://www.hindawi.com/journals/tswj/ 2011/167973/.

7. Mitra S, Roy P (2011) BTEX: A Serious Ground-water Contaminant. Res J Environ Sci 5:394-398. https://scialert.net/fulltextmobile/?doi=rjes.2011.394.398.

8. Agarwal T, Khillare PS, Shridhar V, Ray S (2009) Pattern, sources and toxic potential of PAHs in the agricultural soils of Delhi, India, J. Hazard. Mater. 163 1033-1039. https://www.ncbi.nlm.nih.gov/pubmed/18757133.

9. Hoque RR, Khillare PSS, Agarwal T, Sridhar V, Balachandran (2008) Spatial and temporal variation of BTEX in the urban atmosphere of Delhi, India. Sci Total Environ392:30-40. https://www.ncbi.nlm.nih.gov/pubmed/18067950.

10. Bono R, Enzo S, Schiliro T, Gilli G, (2003) Ambient Air Levels and Occupational Exposure to Benzene, Toluene, and Xylenes in North western Italy, J. Toxicol. Environ. Health Part A 66(6):519-31. https://www.ncbi.nlm.nih.gov/pubmed/ 12712594.

11. Buczynska AJ, Krata A, Stranger M, Godoi AFL, Deutsch VK, Bencs L, Naveau I, Roekens E, Grieken RV (2009) Atmospheric BTEX concentrations in an area with intensive street traffic. Atmos Environ 43:311-318.

12. Zhang Y, Mu Y, Liu J, Mellouki A (2012) Levels, sources and health risks of carbonyls and BTEX in the ambient air of Beijing, China. J Environ Sci 24:124130. https://www.sciencedirect.com/science/article/pii/S1001074211607353.

13. Maræ M, Bielawska M, Wardencki W, et al (2015) The influence of meteorological conditions and anthropogenic activities on the seasonal fluctuations of BTEX in the urban air of the Hanseatic city of Gdansk, Poland. Environ SciPollut Res 22:11940-11954.

14. Masih A, Lall AS, Taneja A, Singhvi R (2017) Exposure profiles, seasonal variation and health risk assessment of BTEX in indoor air of homes at differen microenvironments of a terai province of northern India. Chemosphere 176:8 17.2017. https://www.ncbi.nlm.nih.gov/pubmed/28254715.

15. Nespeca et al. (2019) Ultra-fast gas chromatographic with flame ionization detector (UFGC-FID) and sonication methods for determination of total petroleum hydrocarbons fractions and BTEX in soil, Microchemical Journal 150, 104-163.

16. Ahmed et al. (2019) Assessment of benzene, toluene, ethyl-benzene, and xylene (BTEX) toxicity in soil using sulfur-oxidizing bacterial (SOB) bioassay, Chemosphere 220,651-657.

17. Dhada I, Nagar P K, Sharma M (2014) Challenges of TiO2 Based Photooxidation 
of Volatile Organic Compounds: Designing, Coating, and Regenerating Catalyst, Ind. Eng. Chem. Res. 54, 53815387.

18. Miri M, RostamiAghdamShendi M, Ghaffari HR, et al (2016) Investigation of outdoor BTEX: Concentration, variations, sources, spatial distribution, and risk assessment. Chemosphere 163:601-609. https://www.ncbi.nlm.nih.gov/pubmed/ 27589149.

19. Srivastava A, Joseph AE, Devotta S. (2006) Volatile organic compounds in ambient air of Mumbai-India. Atmos Environ 40:892-903.

20. Singh RK, Ramteke DS, Juneja HD, Pandya GH (2013) Ambient Air Quality Monitoring in Terms of Volatile Organic Compounds (VOCs) Occupational Health Exposure at Petroleum Refinery. Int J Environ Prot 3:22-32. https://www.mdpi.com/ 1660-4601/12/4/4101/htm.

21. Kumar MS, Sivasankar V, Gopalkrishna GVT (2017) Quantification of benzene in groundwater sources and risk analysis in a popular South Indian Pilgrimage City - A GIS based approach. Arab J Chem10:S2523-S2533.

22. Buddhadasa SC, Barone S, Gibson E, Bigger SW, Orbell JD (2002) Method dependency in the measurement of BTEX levels in contaminated soil. J Soils Sediments 2:137-142. https://link.springer.com/article/10.1007/BF02988465

23. I.Srivastava, Shruti Mishra, Pramod Kumar Singh, Tarun Gupta, NaliniSankararamakrishnan, (2018) Fast and efficient removal of Toluene, Ethylbenzene and O-Xylene from aqueous phase by functionalized carbon micro/ nano composites, Journal of Environmental Chemical Engineering,4917-4926. https://www.sciencedirect.com/science/article/pii/S2213343718303877.

24. ChenyeXu,Xinmeng Lin, Shanshan Yin, Kai Liu, Weiping Liu, (2019) Spatiovertical characterization of the BTEXS group of VOCs in Chinese agricultural soils, Science of The Total Environment, Volume 694, December.

25. Kolsoum Dalvand, Alireza Ghiasvand, (2019) Simultaneous analysis of PAHs and BTEX in soil by a needle trap device coupled with GC-FID and using response surface methodology involving Box-Behnken design, Analytica Chimica Acta, Volume 1083, 20 November, Pages 119-129.

26. Kumar V., P. Rajput and A. Goel, (2018) Atmospheric abundance of HULIS during wintertime in Indo-Gangetic Plain: impact of biomass burning emissions, J AtmosChem, https://doi.org/10.1007/s10874-018-9381-4.

27. Jishnu R B., Naik S P., N.R. Patra and J.N. Malik, (2013)Ground response analysis of Kanpur soil along Indo-Gangetic Plains, Soil DynEarthqEng, 51, 47-57.

28. Trapido M., (1999) Levels of PAHs in the soils of Belgrade and its environs, Environ Pollut, 105, 67-74.

29. Hannesin F O S. and Gilham W R., (1998) Long term performance of an In situ iron wall for remediation of VOC's, Ground water, 36, 164-170.

30. Peng M. Vane M Leland M., Liu X Sean, (2003) Recent advances in VOCs removal from water by pervaporation, J Hazard Mater., B98, 69-90.

31. Chan CC, Mundle SO, Eckert T, Liang X, Tang S, (2012) Lacrampe-Couloume G, Large carbon isotope fractionation during biodegradation of chloroform by dehalobacter cultures. Environ SciTechnol;46:10154-60.

32. Justicia-Leon SD, Higgins S, Mack EE, Griffiths DR, Tang S, Edwards EA, (2014) Bioaugmentation with distinct dehalobacter strains achieves chloroform detoxification in microcosms. Environ SciTechnol, 48:1851-8.

33. Li B, Lin K, Zhang W, Lu S, Liu Y. (2012) Effectiveness of air stripping, advanced oxidation, and activated carbon adsorption-coupled process in treating chlorinated solventcontaminated groundwater, J Environ Eng, 138:903-14.

34. Randazzo S, Scialdone O, Brillas E, SirésI.(2011) Comparative electrochemical treatments of two chlorinated aliphatic hydrocarbons: time course of the main reaction by-products. J Hazard Mater 192:1555-64.

35. Rodríguez SM, Gálvez JB, Rubio M, Ibáñez PF, Gernjak W, Alberola IO. (2005) Treatment of chlorinated solvents by $\mathrm{TiO} 2$ photocatalysis and photo-Fenton: influence of operating conditions in a solar pilot plant. Chemosphere 58:391-8

36. Tsai TT, Kao CM, Surampalli RY, Weng CH, Liang SH. (2010) Treatment of TCEcontaminated groundwater using Fenton-Like oxidation activated with basic oxygen furnace slag. J Environ Eng 136:288-94.

37. Wei Z, SeoY. (2010) Trichloroethylene (TCE) adsorption using sustainable organic mulch. J Hazard Mater 181:147-53.

38. Yokosuka Y, Oki K, Nishikiori H, Tatsumi Y, Tanaka N, Fujii T. (2009) Photocatalytic degradation of trichloroethylene using $\mathrm{N}$-doped $\mathrm{TiO} 2$ prepared by a simple sol-gel process. Res ChemIntermed 35:43-53.

39. Benoit V A, (2008) Transgenic plants for phytoremediation: helping nature to clean up environmental pollution, Trends in Biotechnology, 26; 5, 225-227. 